84

Reihe Politikwissenschaft Political Science Series

\title{
Governance: A Garbage Can Perspective
}

B. Guy Peters 

Reihe Politikwissenschaft Political Science Series

\title{
Governance: A Garbage Can Perspective
}

\author{
B. Guy Peters
}

December 2002

Institut für Höhere Studien (IHS), Wien Institute for Advanced Studies, Vienna 


\section{Contact:}

B. Guy Peters

亩: 001-412-648-7250

email: bgpeters@bgpeters+@pitt.edu

Founded in 1963 by two prominent Austrians living in exile - the sociologist Paul F. Lazarsfeld and the economist Oskar Morgenstern - with the financial support from the Ford Foundation, the Austrian Federal Ministry of Education, and the City of Vienna, the Institute for Advanced Studies (IHS) is the first institution for postgraduate education and research in economics and the social sciences in Austria. The Political Science Series presents research done at the Department of Political Science and aims to share "work in progress" before formal publication. It includes papers by the Department's teaching and research staff, visiting professors, graduate students, visiting fellows, and invited participants in seminars, workshops, and conferences. As usual, authors bear full responsibility for the content of their contributions.

Das Institut für Höhere Studien (IHS) wurde im Jahr 1963 von zwei prominenten Exilösterreichern dem Soziologen Paul F. Lazarsfeld und dem Ökonomen Oskar Morgenstern - mit Hilfe der FordStiftung, des Österreichischen Bundesministeriums für Unterricht und der Stadt Wien gegründet und is somit die erste nachuniversitäre Lehr- und Forschungsstätte für die Sozial- und Wirtschaftswissenschaften in Österreich. Die Reihe Politikwissenschaft bietet Einblick in die Forschungsarbeit der Abteilung für Politikwissenschaft und verfolgt das Ziel, abteilungsinterne Diskussionsbeiträge einer breiteren fachinternen Öffentlichkeit zugänglich zu machen. Die inhaltliche Verantwortung für die veröffentlichten Beiträge liegt bei den Autoren und Autorinnen. Gastbeiträge werden als solche gekennzeichnet. 


\section{Abstract}

As I worked through the revisions of this paper I realized that I was to a great extent returning to the dominant themes from one of the first books I ever published. This was Can Government Go Bankrupt?, written with Richard Rose and published in 1978. That book and this paper both deal with the authority of governments and their capacity to govern. Dror (2001) provides a very detailed analysis of governance capacity, but much of that analysis will actually come down to the presence of legitimacy for the governing system, and the capacity to use steering instruments effectively to reach desired collective goals. The issues to be raised in this paper are concentrated primarily on governance questions at the level of central governments and multi-level interactions, rather than of the international system, but much of the same logic of sovereignty/authority is in operation.

\section{Abstrakt}

Während der Arbeit zu diesem Papier wurde mir klar, daß es eine Reihe von Themen reflektiert, die in einem meiner ersten Bücher eine zentrale Stellung einnahmen. Dabei handelte es sich um den mit Richard Rose gemeinsam herausgegebenen Band Can Government Go Bankrupt? von 1978. Buch und Papier handeln beide von Authorität und Handlungskapazitäten von Regierungen. Dror (2001) analysierte Governance Kapazitäten, wobei ein großer Teil der Analyse sich mit Fragen der Legitimation und der Effektivität des Einsatzes von Steuerungsinstrumenten zur Erreichung erwünschter kollektiver Ziele beschäftigte. Im vorliegenden Papier werden die zentralen Punkte die Frage nach Governance auf der Ebene von zentralstaatlichen Instanzen und Multiebenen-Interaktionen sein - weniger als im internationalen System, obwohl auch dort die selbe Logik von Souveränität und Authorität zum Tragen kommt.

\section{Keywords}

Governance, State Capacity, Governance Capacity, Garbage Can Model.

\section{Schlagworte}

Governance, Staatskapazitäten, Governance Kapazitäten, Garbage Can Modell. 


\section{Comment}

B. Guy Peters was Visiting Professor at the Department of Political Science of the Ins titute for Advanced Studies in October 2002. 
Contents

1. The Governance Debate 3

2. The Garbage Can Model 6

3. Organized Anarchies 8

4. Governing in the Garbage Can 13

5. Paradoxes in the Garbage Can 14

$\begin{array}{ll}\text { 6. Conclusion } & 16\end{array}$

$\begin{array}{lr}\text { 7. References } & 18\end{array}$ 

Governance is a very old concept, and an even older reality. Societies have always required some form of collective steering and management. Variations in the political and economic order have produced different answers to the fundamental questions about how to provide that steering for society, and how to cope with the range of challenges arising from the society, but some answer has been required, and continues to be required. Governance is not a constant, but rather tends to change as needs and values change. The usual answer to the questions has been the State, but solutions that have been effective, and popular with the public, at one point in time may rather quickly become both ineffective and politically unpopular. The process of governing represents a continuing set of adaptations of political and administrative activities to changes in the environment, not least of which are changes in the ideas of what constitutes appropriate modes of developing and implementing collective goals. ${ }^{1}$

We need to understand and emphasize an adaptative capacity in contemporary governance. For a variety of reasons the assumptions upon which much of what may now be deemed "traditional" approaches to governing are subject to question. In particular, assumptions about the centrality of the nation state and the centrality of authoritative public actors in governance are subject to question. Stated differently, the notion of a single locus of sovereignty and of a hierarchical ordering within the system of governance simply can no longer be accepted as reasonable descriptions of the reality of governing. As yet, however, there are no generally accepted replacements for those guiding assumptions and as a consequence both the academic world and the real world of governance are more problematic than they have been in the past.

This paper will address some of those issues in governing, and attempt to provide one means of understanding the changes. The answer provided here, if indeed it is an answer, may be somewhat unsatisfying because it will focus on the indeterminacy of governance in a world without those guiding assumptions. The approach that will be developed, however, may better reflect the reality of governance than more deterministic models. Further, adopting such an unstructured approach does not mean that decisions are not made, and we will be arguing that decisions are made and not always in the open and participative ways implied by some of the literature on changes in governance. The absence of these guiding assumptions about the location and use of authority in governing means that decision situations are becoming more unstructured, so that a variety of influences are brought to bear on policy choices, whether for foreign or domestic policies.

The shifts in governance styles involve corresponding shifts in the instruments used for governing, as well as in the content of governing. Shifts in the content and goals of

1 The use of the word appropriate here is deliberate, representing the influence of the (March and Olsen, 1989) "logic of appropriateness" as a basis of institutions. 
governance are the more obvious of the transformations. This change in solutions to the basic questions of the political economy was obvious during the 1980s and 1990s as most countries of West Europe, North America and the Antipodes adopted neo-liberal ideas of the role of the state, and reduced the role of the public sector significantly (Campbell and Pedersen, 2001). The transformations of the goals of governing in Eastern Europe and some countries in the Third World, driven in part by international organizations and other donors, were even more dramatic. Likewise, the welfare state continues to be redefined as neoliberal ideas shape the manner in which governments manage social problems of inequality and providing income for people over the life-cycle. ${ }^{2}$

No matter what the overall goals and content of governing may be, there are a range of instruments available to achieve the goals. The instruments literature (Salamon, 2002; Peters and Van Nispen, 1998) coming from public administration and public policy has concentrated to a great extent on understanding these "tools" at the level of the individual tool. That is, how does a loan guarantee differ from a voucher as a means of putting a program into effect. ${ }^{3}$ At a more general level, however, changes in governing have tended to entail movements away from authority based instruments and to involve governments working through less intrusive means. In the terminology developed by Hood (1986), there has been a shift away from authority based instruments in favor of instruments based on treasure and nodality (information). In particular, the "new governance" involves using the financial resources of the public sector to leverage the involvement of significant private sector actors (...).

The movement away from authority based instruments and ruling through those conventional mechanisms of social control has occurred in large part because of a variety of changes occurring within government itself, and perhaps more importantly because of changes in public reactions to the actions of the public sector. There is by now a significant literature documenting the declining public confidence in government institutions and in the politicians who populate them (Norris, 1999; Dogan, 1999). This decline in public confidence in government has been most pronounced in the United States (Bok, 1997) but it has been observed even in countries with a long histories of benign and effective government (Holmberg and Weibull, 1998; Ministry of Finance, 1998).

With the decline in confidence in government the capacity to achieve goals through instruments that depend upon authority, and therefore upon legitimacy, is diminished. One strand of the instruments literature (Phidd and Doern, 1978; Woodside, 1998) has stressed the importance of less intrusive means of governing, but that point is now being forced upon governments. Further, as intimated above, the declining confidence of the public has led to

2 (For a rather extreme view see Pierson, 1994; for a more tempered view see Fawcett, 2002).

3 For a more skeptical conception of the tools approach to governance see Ringeling (2002). 
shifting service provision to the private sector, whether the organizations involved are for profit or not for profit.

As well as a generalized debate over the capacity of governments to govern, there is a more particular debate over how governments can govern, and the appropriate distribution, or melding, of authority among types of government. Given that the loss of public confidence has been most pronounced for national governments, decentralization has become a frequent strategy for maintaining effective governance (ACSI, 200). Both the choice of decentralization and the choice to utilize private sector organizations are conscious strategies, designed to sauve qui peut. Grande and Pauly (2002) remind us that some, if not most, of the erosion of governance capacity has not been dealt with systematically, and the dynamics of the international political and economics systems have pervasive consequences for governance.

\section{The Governance Debate}

Changes in the reality of governance have been significant and have transformed what governments do, as well as how they do it. ${ }^{4}$ The changes in the academic debate concerning governance have been, however, at least as pronounced as those within government. In the first place, there is now an active governance discussion, rather than having scholars assume that societies would and could continue to be governed as they had always been. Further, the changes in the academic discourse have paralleled the transformation of governing in the real world and have attempted to provide some interpretation of those changes. The important shift in the academic literature is represented by the very use, and now the wide spread use, of the term "governance," rather than terms such as government, the State, or even ruling, to describe how steering is accomplished within society.

The concept of steering is central to this discussion of governance, with the basic idea being that there must be some mechanism for making and implementing collective goals for society. By positing this basic requirement governance research we can then consider how that need is fulfilled. ${ }^{5}$ This approach to the analysis of governance is much like the implementation literature in which scholars posited a basic requirement to put law into effect and then the extent and manner of making that happen becomes the basis of comparison.

4 See, for example, the European Union "White Paper on Governance" and the wide range of responses to that paper.

5 If we do posit the need for steering then the governance literature does have some element of functionalism. Steering becomes, in essence, a functional prerequisite for a society, with the question then becoming how to fulfill that prerequisite (see Peters, 2002). 
Although anchored by some concept of steering, students of governance have been somewhat like the Lewis Carroll's character who makes the term mean exactly what he wants it to mean. As the literature has developed the term governance has taken on a wide range of meanings. At one end of a dimension of State involvement governance means very much what has been "government," with the State remaining the most important actor in steering, and authority the means through which the State steers society. Despite pressures from globalization, from declining public confidence, and from decentralization of policymaking the argument of the State-centric approach is that the only actor, or set of actors, capable of collective goal setting and goal attainment is central government. Indeed, globalization in this view may strengthen the need for strong, effective and above all democratic, government provided through the nation State (Hirst, 1999; 2000). In less extreme versions of the State-centric approaches government remains an important player in governance, but must also involve itself in partnerships and other arrangements with societal actors in order to be more effective.

At the other end of this dimension some scholars (see Rhodes, 1996; 2000) have argued that the state has become, if not totally superfluous, then extremely ineffective. The argument put forward the "governance without government" school is that society is now sufficiently well organized through selforganizing networks that any attempts on the part of government to intervene will be ineffective and perhaps counterproductive. Society is presumed to be better able of understanding its own affairs and of finding remedies for any problems that are encountered in its functioning. In that context, government becomes a bureaucratic and rather clumsy structure for making decisions. Further, the autopoetic, selforganizing nature of society is taken in these approaches to mean that society will be able to avoid or deflect any attempts on the part of governments to control its affairs - government in essence becomes dispensable and expensive. ${ }^{6}$ This view about the declining steering capacity of government is based largely on domestic factors, in contrast to others that consider the role of the state as an international actor.

In between the two extremes of governance we can find approaches to the concept that recognize that societal actors have assumed an increasing involvement in governance activities, just as the state has had an increased level of involvement in what are presumably private activities and organizations (Bozeman, 1986). In these more moderate versions of governance ideas the process of steering involves an interaction of the public and the private sectors, and also an interaction between top-down and bottom-up conceptions of how society can be steered. While less sharply defined than the more extreme versions, these more temperate versions of governance represent somewhat more accurately the complexity that is entailed in contemporary governing. These moderate conceptions of governance are represented in part by the "Dutch school" of governance, that considers governance a

6 These ideas are, of course, derived in large part from the work of sociologists such as Niklas Luhmann. 
"socio-political" process (Kooiman, 1993). In this version of the process networks of societal actors are heavily involved in providing governance, yet do so in cooperation with, and to some extent under the direction of, the state actors. Governance in the Dutch and similar models is cooperative rather than adversarial, with policy outcomes resulting from overcoming the decisional and coordination problems inherent in large complex policy arenas.

We should also consider that some forms of governing through authority sharing rather than imposition could be seen as intermediate forms of governance. For example, the welldeveloped discussion of corporatist and corporate-pluralist models popular during the 1970s and 1990s (Schmitter, 1974; Olsen, 1978; Wiarda, 1997) was presenting a variety of available mechanisms for linking state and society in governance. The State remained an active, and in some cases essentially dominant, player in these proceedings but yet there was bargaining and mutual accommodation in making policy. Further, societal actors have been involved in implementing policies for decades if not centuries, so that the output side of government has been linked effectively with society for some time. Any number of public policies depend upon private sector or not-for-profit organizations to implement programs in the name of government, whether to save resources or to create more effective and humane service delivery.

Factors other than political change are also involved in driving shifts in the prevailing styles of governance. The nature of the problems confronting governments also have changed, and changed in several ways. The most fundamental transformation in the environment of the public sector is that change itself - technological, social, economic - tends to be more rapid and less predictable than in the past. Whether the extreme versions of change associated with chaos theory (Morçöl, 1996 ) or more moderate versions of unpredictability in the environment are considered the best way to consider environmental change, governments must find ways of coping with rapidly changing problems and a socio-economic environment that is less predictable than in much of their previous experience. This change in governance will require enhanced flexibility, and with that flexibility comes designs for governance that recognize the modification of preferences through learning (Sabatier, 1988) and the inadequacy of many technologies for achieving programmatic goals. Decisions that once might have been programmable will, under these circumstances, be more subject to circumstance and opportunities, rather than planning and formalized procedures. ${ }^{7}$ Not all policy problems and decision situations will become so chaotic; many will be little changed and the same actors and the same problem definitions will dominate.

7 In Weber's terminology these simplistic problems and products of government are "mass goods;" Mintzberg speaks of the "machine bureaucracy." 
Associated with the increasingly rapid pace of change in many policy sectors is a shift in the involvement of actors in governing. On the one hand many traditional actors in governing are becoming weakened, perhaps most notably political parties. On the other hand, there is a wider variety of organizations that are organized sufficiently to exert some pressure on government.

The concept of governance therefore confrims that there has been a shift away from an authority based style of governing that has assumed the capacity of governments to exercise hierarchical control over society. Governance is one of several terms used to describe that change. Governance when taken to the extreme attaches little importance to state actors in providing collective steering for society. I am not adopting anything near such an extreme conception of governance, and am retaining a stronger role for the state than in the extreme versions. Even this moderate perspective, however, does ascribe a lesser role to the state than the state-centric assumptions that have guided a good deal of work on governing, and also directs us to think about steering in less deterministic manners.

\section{The Garbage Can Model}

Although there has been a good deal of thinking and writing about governance, the term remains largely descriptive rather than explanatory. This descriptive nature of a great deal of the governance literature reflects in part its attempt to capture virtually the entirety of the policy process, becoming something of a later day systems analysis, or structural functional analysis, of politics (Peters, 2002). To the extent that the term is used less generally the concept often relies upon network thinking, and is hampered by the absence of mechanisms of conflict resolution and decision-making in that body of theory. Politics is about contradictory and conflicting interests and the argument that social networks are capable of governing is contingent upon their capacity to resolve those differences.

Whatever approach one may take to governance, save the most State-centric, the very use of the term governance represents an acceptance of some movement away from the conventional authority-based style of governing. That movement is in favor of approaches to governing that rely less on formal authority and more on the interaction of State and society actors. Further, the questioning of state authority and capacity implied in the use of governance means that some of the rationalist perspectives on the role of governments in governing may also be brought into question. ${ }^{8}$ The "new governance" literature stresses networks, bargaining, and interaction rather than hierarchies as the best way to govern, and

8 These rationalist assumptions are perhaps clearest in the international relations literature that has focussed on the State as a unitary actor pursuing its goals - Allison's rational actor model. Even in the domestic politics literature, however, there is sometimes a tendency to anthropomophize the State. 
the best way to understand governance. Thus, this literature contains both normative and empirical dimensions.

One way to move beyond a strictly descriptive treatment of governance is to employ the garbage can model of organizational behavior developed by Cohen, March and Olsen (1972). This model provides a means of exploring the ways in which governance can be supplied in a world that is less clearly governed through authority and hierarchy. Based, not surprisingly, on the management of universities (see also March and Olsen, 1976), the garbage can model rejected conventional linear models of organizational decision-making in favor of a less determinate and less rational (in the usual interpretation of that word) forms of making decisions. The fundamental assumption driving this model is that, rather than being programmed or predictable, decisions in many situations are more the result of the serendipitous confluence of opportunities, individuals and ideas (see below).

The garbage can was developed as a means of examining the behavior of organizations, but its authors discussed the possibility of its being applied to "decision situations" as well as to organizations per se. Further, at least one of its authors of the original article has discussed the possibility of its application to the European Union as a relatively diffuse, unstructured political system (Olsen, 2001). ${ }^{9}$ Likewise, Christopher Hood (2000) has examined the relationship of this model to governing somewhat more generally, focussing on the relationship of unstructured decision-making situations to risk and regulation. The model does appear to have some utility for understanding decision situations that are broader than individual organizations, and may well be applicable to situations in which individual organizations themselves are the principal players. We will be arguing that in these broader decisional settings organizations may be the most integrated and decisive actors in what is in many ways an anarchic decision situations, and therefore the organizations will have some advantages in producing actions that conform to their preferences, or at a minimum in blocking their least preferred alternatives.

The garbage can model of organizational decision-making is one link in an extended chain of intellectual development in strand of organizational theory that is described as "bounded rationality," and is founded upon the insights of Herbert Simon and other members of the socalled Carnegie School of decision-making (1947; March and Simon, 1957; Cyert and March, 1963; see Bauer and Gergen, 1968). Simon famously argued that the demands of full blown rationality were too great for any individual or any organization to be able to achieve when making decisions. Therefore, organizations are best understood as acting rationally

9 See also Richardson (2001) for a brief application of some of these ideas to the European Union, focussing on the loosely structured nature of the process through which decisions are made. That is, although there is a process that does generate decisions, the multiple actors, the variety of interests, and the absence of integrating actors such as political parties makes the processes within the EU less capable of management (especially by political leaders) than analogous processes within national governments. 
only within narrowed boundaries, with their range rational action determined by their own routines, norms, technologies, and interests. Thus, Simon's familiar concept of satisficing can be used to describe behavior that seeks outcomes that are "good enough" rather than comprehensively utility maximizing. This criterion of rationality should not be seen, however, as excessively minimalist given that finding policy solutions that are "good enough" can itself be extremely demanding, and is rational from the perspective of minimizing decision-making costs rather than maximizing the utility of the outcomes produced.

We will be arguing that the garbage can model is capable of being used to understand governance in the political environment described by Grande and Pauly (2002). In particular, given that the capacity of authoritative actors to structure decisions has been diminished, and that even many structured modes of political participation have been weakened, the garbage can appears to be more applicable. With those changes both the inputs into politics and the processes by which decisions are reached are less predictable, and less likely to be effective on a regular basis. The outcomes of the policy process may represent the confluence of streams of possibilities rather than a rational search for the best option. This model of governing is itself not predictive, but it does provide a useful means for interpreting many changes in contemporary governance.

\section{Organized Anarchies}

The garbage can model grew out of the general concern with bounded rationality within organizations, and other decision-making situations, in which linear and fully rational modes of choice would be unlikely if not completely impossible (see Jones, 2001). Although Bendor, Moe and Shotts $(2001,174)$ find reasons to distinguish the garbage can model from the remainder of the bounded rationality literature, there does appear to a strong family resemblance, if not a direct parental connection, among these approaches to organizations and decision. If nothing else the garbage can and bounded rationality both reject fundamentally rationalist perspectives, and seek alternative means of understanding how institutions are able to muddle through in complex and poorly defined decision situations. As for the organized anarchies that are central to the garbage can, three features characterize these organizations or situations:

\section{1) Problematic Preferences:}

In a setting such as that assumed to exist within an organized anarchy, it is difficult to impute the consistency of preferences that are required for standard, rationalistic models of decision-making to perform well. Preferences in the model of the garbage can are inconsistent among the participants and/or ill-defined. Further, preferences may be subject to limited discussion because of the political difficulties that such inconsistency may generate within an organization, or a political system. The point here is that preferences held by 
individual actors may well be consistent, and could be held quite passionately, but preferences within the decision-making structure as a whole are not consistent.

In an organized anarchy preferences are discovered through actions. Note that in this context individual actors (individual or collective) may have consistent preferences, but the policy making system qua-system is assumed to encounter substantial difficulty in reconciling those varied preferences and making them coherent. The shifts characteristic of a post-authority governance make resolving any conflicts all the more difficult. Those difficulties are analogous to those political scientists have identified with "blocked" policymaking or "stalemate" for some time (see, for example, Crozier, 1979), but these blockages may be more severe because of the decline of authority based instruments for resolving blockages.

To the extent that it can move, the organized anarchy consequently faces the danger of falling into something like a "joint decision trap," with decisions being made by the lowest common denominator (Scharpf, 1996). Scharpf's analysis is based on policymaking within the Union, as well as the federal government in Germany. The EU is a locus classicus of shared and complex sovereignty and with that multiple and competing preferences; Sbragia (2000) refers to the EU as an "ambiguous political space." These anarchical tendencies are all the more true given that national governments tend to have conflicting views about levels of integration, often based on individual policy areas in which their own economy is likely to benefit or lose from shifts in control over the sector.

If preferences are discovered for the system as whole, rather than being imposed through authority and sovereignty, then the only ones available may be minimal movements away from the status quo - the classic incremental solution to policy problems. This behavior is itself consistent with the logic of bounded rationality, and can be seen as rational from that perspective (Cyert and March, 1963). If there are to be movements away from this minimalist form of governance through accepting only the points on which there is agreement, then intersections with at least one other stream within the garbage can - either individuals as entrepreneurs or opportunities (crises, windfalls or whatever) may be necessary. For example, the rather lurching movements of European integration can be conceptualized as the intersection of preferences with defined opportunities such as Amsterdam and Nice.

\section{2) Unclear Technology:}

The processes through which organized anarchies are able to survive, and even to prosper, are often poorly understood by the members of those structures. There may be a rather simple trial and error process of learning, and incremental change in the system, but the structuring of the system is largely done by adaptation rather than comprehensive strategic planning from the center. Thus, just as the goals of governing may emerge rather than being imposed from a central "mind of government," so too are the means of achieving those ends also likely to be emergent rather than planned. 
This absence of clear and centrally controlled technologies for governing is consistent with a good deal of contemporary discussions about governance. Whereas government might once have had well-known and accepted means of implementing policy and producing the actions that were required there is now a less clear armamentarium available to would-be governors. The good news in this is that there is a wider range of instruments available for government to use when implementing its programs, many of which involve using the private sector. Part of the wide scale reform of government over the past several decades (Peters, 2001) has been to create means of achieving collective purposes through less direct, partnership methods (Pierre, 1997), or other means involving private and not for profit actors.

As well as a wider range of "technologies" for achieving ends for the public sector, the very lack of clarity inherent in the "garbage can" model of governing may be an advantage of the emergent public sector. While the more traditional public sector and its limited range of responses to problems (and opportunities) may have been able to produce results, it did so at some cost, and the lack of clarity that is typical of bounded rationality and its more evolutionary and trial and error style of governing has the potential for political benefits if not necessarily for enhanced effectiveness in governing.

This emergent style of more tentative governing may be an antidote to the need of many governments, and many politicians, to claim that they have the answers for the problems that confront society. While claiming that solutions to policy problems are not only possible but even readily available may be politically necessary at times, it may not reflect the reality of the knowledge base available to governments when attempting to govern in many of policy areas. Several decades ago the economist Richard Nelson (1968) argued that governments did not have the technology to cope with most social problems. ${ }^{10}$ Regrettably that conclusion still stands, so that the public sector is often making decisions without clear understanding of the process into which it is intervening. Given that weakness of the knowledge base available to many decision-makers, and the associated uncertainty about policy, recognition of the problem and a willingness to avoid premature closure of policy options may represent a more "rational" approach to governing than a more selfassured approach.

10 Nelson contrasted the success of government in getting a man on the moon with the lack of success in dealing with the social problems of the ghetto. The former involved using a known, if highly complex, technology, while the latter task could use no known technology and hence was a much more challenging task for government; see also Moynihan (1973). 


\section{3) Fluid Participation:}

Members of organized anarchies vary in the amount of time and effort they are prepared to devote to any structure or situation, and indeed membership in such an anarchy may itself be problematic. Thus, the boundaries of the organizations, or the decision situations, are fluid and uncertain, and the decision-process within then tend to be poorly defined. The attempts of any actor to become involved in any decision may be capricious, and certainly can not be readily predicted, even from prior analogous situations. Given the game-like nature of this process the potential participants never totally ignore the possibilities of involvement; they may choose the degree of involvement depending upon the perceived probabilities of winning, or perhaps on the basis of less utilitarian criteria.

This description of life in an organized anarchy bears some resemblance to discussions of policy-making in networked governments (Kickert, Klijn and Koopejans, 1997). In the conventional state-centric conception of governing participation in the policy process might be managed in one of several ways. Perhaps most importantly the principal players would be governmental actors, rather than actors from civil society, and they would be mandated to participate or would find it in their political and/or organizational interest to participate. To the extent that elements of civil society are involved in the policy process their participation tends to be organized by the state, rather than being the autonomous decisions by those actors themselves. That structuring of participation may be through pluralist selection of a limited number of quasi-official representatives of societal segments, or it may be more corporatist or corporate pluralist in which multiple interests are brought together in an official decision process (Schmitter, 1974; Rokkan, 1976). These structures are capable of creating more integrated preferences for the society and the segmentation that characterizes much of government can be alleviated through these participatory mechanisms.

This characteristic of erratic and uncertain participation does not necessarily mean that there will be less participation. In fact, it may mean quite the contrary. As state-imposed constraints on participation become more relaxed then there are more demands for involvement, and also more participation in decisions. Charles Jones (1982) argued some years ago that the "iron triangles" in American politics had been transformed into "big sloppy hexagons," but the geometry of political participation can now be described only by more complex structures. At the same time that societies are presumably becoming more atomistic and less organizational, the level of mobilization around particular issues remains strong, or has perhaps even increased in intensity (Tarrow, 1998). This is certainly political participation but it is not the conventional versions. It may be that we are not necessarily bowling alone; rather we may simply be bowling in new leagues each week.

The above point about shifting forms of participation raises yet another issue concerning the nature of societal participation in this "garbage can model" of governance. The nature and structure of the groups attempting to participate in government are changing in a manner that emphasizes the fluid and uncertain nature of contemporary governance. There is a good 
deal of evidence that involvement in the available range of stable political organizations both interest groups and the traditional political parties - that were deeply embedded in the political process is declining. In there place there a number of short-lived, and/or single issue organizations have begun to attract greater participation. We may speculate about the reasons for the apparent failure of the traditional interest groups and parties as the mechanisms for political mobilization (Dalton and Wattenberg, 2000), but that they are less capable of channeling participation does appear clear.

The decline in political participation through conventional means rather obviously enhances the fluidity of participation in government and hence some of the predictability of the process. This fluidity affects not only the types of pressures being placed on decision-makers but it also affects the political calculations that those decision-makers are likely to make about policies. In a less fluid process the decision-makers can calculate the likely political consequences of decisions, even if they may be uncertain about the effectiveness of the policies being adopted. ${ }^{11}$ This aspect of fluid participation is closely related to the problematic nature of preferences in an organized anarchy. Again, individual actors have preferences and hold them with some intensity, and perhaps with even greater intensity than in more structured situations of decision-making, but their multiplicity and the fluidity of participation makes integration across the policy system more difficult than in a more structured system. ${ }^{12}$

A final point about the more uncertain nature of participation in contemporary governments is that more participation appears to be directed at the output side of government rather than at the input side. That is, rather than worrying about attempting to influence the policy decisions made by legislatures or political executives, a greater share of political activity is becoming directed at influencing the behavior of bureaucracies. Further, it is not only the top of the bureaucracy, but rather at the lowest levels of the administrative system. Members of the public as well as organized interests now find it more useful to limit attempts at exerting influence to local schools, or their own housing projects, or local environmental problems (Sorenson, 1997), rather than acting on a national scale. This may make perfect sense in terms of the capacity to change policies and programs that have direct impacts on the individual, but it also directs the emphasis of policy making on the particular rather than on general policies and their (possible) coherence.

11 For a discussion of the differences between success from policy and political perspectives see Bovens, 't Hart and Peters (2001).

12 More continuous participation in decision-making may, it could be argued tend to make preferences more consistent across the system. For one thing, the need to continue to participate in what is an iterative game may force actors to moderate their views and to cooperate more. 


\section{Governing in the Garbage Can}

The above discussion of the nature of organized anarchies at the heart of the garbage can model may well make one pessimistic about the possibilities of governing in a post-authority political system. That pessimism would, of course, be based upon accepting the notion that the garbage can is a reasonable approach to understanding contemporary governance. While I would not argue that this is the only way in which to approach governance in this significantly altered environment, I would argue, as above, that it does provide a reasonable and useful window on the process of governing. The three properties of the organized anarchy are, as noted, descriptive of many aspects of contemporary policymaking.

The next step in using this approach is to consider the way in which decisions are made in the contest of an organized anarchy. The basic argument of the garbage can model, given its anarchic basis, is that decision-making is not structured, orderly and "rational" in the way that might be expected from much of the decision-making literature in policy analysis and allied fields (Nurmi, 1998). Rather, decision-making in the public sector as seen through the lens of this model reflects the serendipitous, and almost accidental, confluence of streams of problems, solutions, opportunities and actors. In this view the rationalistic conception of problems searching for solutions and actors pursuing their interests in a purposive manner is replaced by decision-making that may be dominated by the appearance of opportunities. As John Kingdon (1995) has argued "policy windows" open and then policy entrepreneurs must be prepared to exploit the opportunities.

This basic description of policy-making in organizational settings has, we will argue, parallels in decision-making in contemporary political systems. There may have been a heyday of rationalist policy-making, but the contemporary world of governance does not appear to be it. ${ }^{13}$ As faith in government has dropped, the faith in rational planning, forecasting, and other forms of rational decision-making has dropped even more rationally. This does not mean that the quest to make "government work better and cost less" has waned, and if anything the reforms of the past several decades indicate quite the opposite. There are continuing attempts to improve government performance, but these depend more upon the use of market or political power to impose greater efficiency and responsiveness, rather than depending upon rational processes to produce optimal answers to policy problems. ${ }^{14}$

Agenda-setting is a crucial aspect of policy-making in the garbage can model. That is true of all approaches to public policy, but the loose structuring of the organized anarchy, and the

13 More accurately there may have been a period in which reformers believed that they could transform complex and often chaotic systems of governing into more rational, planned systems. The captivation of reformers with techniques such as PPBS and indicative planning were examples of the pursuit for rationality and efficiency.

14 Devices such as performance management that are central to contemporary management reforms are more akin to incremental solutions of trial and error than they are to rational planning systems (see Bouckaert, 1995). 
absence of dominant institutional drivers in the system means that deciding what issues will be considered is crucial for deciding outcomes. The model of convergent streams and problematic preferences means that issues that might rationally be considered important for governing may be avoided. Avoidance is one of the more common outcomes of the computer simulations of decision-making in the garbage can, given that the absence of coherent preferences and of a mechanism for driving action ahead. In the context of the European Union there is a similar tendency to avoid decisions until there is adequate agreement to make the decision process (relatively) non-conflictual.

Other studies of management taking the garbage can perspective have found that individual entrepreneurs become the crucial means of producing action (Padgett, 1980). This finding is, of course, not dissimilar to Kingdon's argument about agenda setting in government but research in private sector and third-sector organizations also demonstrates that individual involvement and entrepreneurship are crucial for generating collective action. The centrality of individuals is not only a consequence of their personal power and political skills, it may also be a function of the uncertainty of the situation and the desire of participants to be able to associate proposals for resolving the issue with individuals who advocate them. Further, the research on crisis management points to the need for individuals to "keynote" and define the nature of the crisis before effective organizational action can proceed.

\section{Paradoxes in the Garbage Can}

The seemingly irrational and disorderly assumptions characteristic of the garbage can model, and to some extent of much of the "new governance" literature, masks more determinate patterns of policy-making that belie the seemingly unstructured, chaotic pattern of making decisions. We have examined elsewhere (Peters and Pierre, 2001) the "Faustian bargain" that is implied in multi-level governance, and many of the same normative and empirical questions appear to exist within models of governance more generally, and within the garbage can conception that we are exploring in this paper. The loose structuring and seemingly participatory nature of the arrangements within the garbage can hide rather effectively the exercise of power, and the ability of a limited number of actors to shape outcomes.

The most fundamental paradox is that a system of governance that is assumed to be (and in the case of multi-level governance is designed to be) open, inclusive, and indeterminate may be more determined by power than are more structured systems. We have already noted that from an agenda-setting perspective issues that are appropriately formulated, that is they match some of the preconceptions of individuals and organizations charged with making decisions, are more likely to be successful than are less clearly defined issues and ideas. As Heimer and Stinchcombe (1999) have argued, pressing an issue that is not formulated 
"appropriately" for a decision situation may be dismissed simply as complaining, and the outcome may be quite opposite of that which was intended.

The garbage can model may place an even greater emphasis on agenda-setting than do other varieties of decision-making. Given that the garbage can depends upon a confluence of streams, and the emergence of opportunities for action, one may not expect a great deal of ex ante preparation of issues by public sector actors. Much the same absence of planning of decisions can be assumed of networks that reside at the heart of a great deal of governance thinking in contemporary academia, as well as among active participants in the process of governance. ${ }^{15}$ The absence of authority at the heart of this model makes the emergence of issues more uncertain than it might be in more routinized and regulated structures for decision-making.

If we consider the remainder of the policy process, some of the same dominance of actors who are well integrated into that process, and who can exercise some form of power within the process, also can be observed. Governance ideas, and especially the garbage can conception of governance being utilized in this paper, do imply more loosely structured, indeterminate, and uncertain processes of steering society than those characterizing traditional hierarchical forms of governing. However, as at the agenda-setting stage, the policy formulation stage of the process may be dominated by actors who have clear ideas and who are able to put those ideas into operational forms. Perhaps most obviously bureaucratic organizations are accustomed to translating their conceptions into policies so are likely to be major players when there are fewer hierarchical constraints.

As significant source of the advantage for more powerful actors is the general absence of legal frameworks within which the garbage can functions. Formal rules, and especially constitutional rules, are mechanisms for ensuring access, and protecting minority rights in the decision-making process. Part of the logic of the garbage can model is that there are few formalized rules governing the interaction of the actors, and the actors themselves make most of the decisions about involvement. Further, the governance literature tends to deemphasize formal rules in favor of negotiation, networking and bargaining. Although those terms are neutral and appear benign, the more powerful tend to be most effective in all of these processes, everything else being equal.

Having an answer to the policy problem, and having clear preferences, also tends to favor the more powerful actors in the decision-making process. As noted above, the advantage of having clearly defined preferences is enhanced when there are fewer rules and formalized procedures. In such a decision-making system it may not be the societal actors who might to have been advantaged by a shift toward a governance model, but rather it may be 
bureaucracies and other formal institutions that are able to prosper in that setting. Thus, the garbage can may be a natural locus for bureaucratic politics ${ }^{16}$ rather than the locus for more open and effective participation by societal actors - the presumed winners in governance. This is, of course, exactly the opposite of the expected outcomes of a model of decisionmaking that appears as loosely structured as does this one.

Another component of the advantage for bureaucracies and other institutional actors in a governance or garbage can situation is the control of information. Management scientists who have used the garbage can model to understand organizational processes found that control of information was crucial to controlling the decisions of those organizations (Padgett, 1980). We should expect that bureaucracies would gain a substantial advantage here over societal actors, despite the attempt of those actors to enhance their capacity to provide alternatives to official views of policy, or even the actions of governments to create paid intervenors and other information alternatives (see Gormley, 1983). Information is crucial in all decision processes but its power may be enhanced when the process is itself poorly defined, and the problems become defined along with the solutions.

\section{Conclusion}

This paper has been an exploration of whether the concept of the garbage can developed as a means of understanding behavior in organizations can be used to understand governance in the contemporary public sector. The principal reason for pursuing this concept is that the apparent decline in the authority of the State in governing has produced some of the same conditions in the public sector as a whole that were presumed to exist in the "organized anarchies" within organizations. We have argued that there are sufficient analogies between these two decision situations to permit using the garbage can with reference to contemporary governance. In particular, the declining level of structure in the manner in which demands are being made on government, and the apparently greater difficulty in making cecisions within government, appear to make the analogy with the garbage can viable.

Not only is the analogy between organizational and more comprehensive and politicized forms of policy-making viable, but it is also useful. By looking at the process of governing as analogous to the garbage can model of organizational decision-making, we can begin to understand better the implications of changes in the capacity of governments to impose their programs through authority-based mechanisms. In particular, the uncertainty of technology

16 We have made the similar argument (Peters, 1992; Peters and Pierre, 2001) that the European Union and its governance arrangements tend to become bureaucratic politics in the face of the need to steer in a complex and largely unstructured situation. 
and the difficulty in making preferences coherent given the increased variety of participants in the process may help to explain the difficulties many governments now encounter when making decisions. Governance is a game that many people and organizations get to play, and that wider participation and some uncertainty about the rules makes outcomes less predictable. These same characteristics of policy processes may be found in international settings with multiple sovereignties at play.

Perhaps the most important outcome of this analysis is that the rather benign assumptions of much of the governance literature may disguise some less open and democratic implications of the concept. While governance implies wider participation, the analogy with the garbage can would lead us to expect power to be as important or even more important than in statecentric conceptions of governing. The role of political and institutional power may be especially pronounced when governments are forced to think and act horizontally, and to attempt to create more coherent patterns of governing. That integration across issue domains may be achievable only through the use of some form of power, whether derived from expertise or position. If governing is providing a relatively coherent set of priorities to society, then governance may find power and authority have not been lessened but only redefined. 


\section{References}

Bauer, R. A. and H. Gergen (1968) The Study of Policy Formation (New York: Free Press).

Bendor, J., T. M. Moe and K. W. Shotts (2001) Recylcing the Garbage Can: An Assessment of a Research Program, American Political Science Review 95, 169-90.

Bok, D. (1997) Measuring the Performance of Government, in J. S. Nye, P. Zelikow and D. C. King, eds., Why People Don't Trust Government (Cambridge, MA: Harvard University Press).

Bouckaert, G. (1995) Improving Performance Measurement. In A. Halachmi and G. Bouckaert (Eds.), The Enduring Challenges in Public Management, Surviving and Excelling in a Changing World (San Francisco: Jossey Bass).

Bovens, M.A. H., P. 't Hart and B. G. Peters (2001) Success and Failure in Public Governance (Cheltenham: Edward Elgar).

Bozeman, B. (1987) All Organizations are Public (San Francisco: Jossey-Bass).

Campbell, J. L. and O. K. Pedersen (2001) The Rise of Neoliberalism and Institutional Analysis (Princeton, NJ: Princeton University Press).

Cohen, M., J. G. March and J. P. Olsen (1972) A Garbage Can Model of Decision-making, Administrative Science Quarterly 17, 1-25.

Crozier, M. (1979) On ne change pas la societe par decret (Paris: B. Grasset).

Cyert, R. and J. G. March (1963) A Behavioral Theory of the Firm (Englewood Cliffs, NJ: Prentice-Hall).

Dalton. R. and B. Wattenberg (2000) Politics Without Partisans (Oxford: Oxford University Press).

Dogan, M. (1999) Déficit de confiance dans les démocraties avancées, Revue internationale de politique comparée $6,510-47$.

Dror, Y. (2001) The Capacity to Govern (London: Frank Cass).

Gormley, W. T. (1983) The Politics of Public Utility Regulation (Pittsburgh: University of Pittsburgh Press). 
Grande, E. and L. W. Pauly (2002) The Reconstitution of Political Authority in the 21st Century, Framework Paper, Munich Conference.

Heimer, C. and A, Stinchcombe (1999) Remodeling the Garbage Can: Implications of the Origins of Issues, in M. Egeberg and P. Laegreid, eds., Organizing Political Institutions: Essays in Honor of Johan P. Olsen (Oslo: Universitetsforlaget).

Hirst, P. Q. (1999) Globalization and Democratic Governance, Paper presented at Triennial meeting of International Political Science Association, Quebec City, July.

Hirst, P. Q. (2000) Democracy and Governance, in J. Pierre, ed., Debating Governance (Oxford: Oxford University Press).

Holmberg, S. and L. Weibull (1998) Opinions Samhallshället (Gothenberg: SOM Institut, University of Gothenberg).

Hood, C. (1986) The Tools of Government (Chatham, NJ: Chatham House).

Hood, C. (1999) The Garbage Can Model of Organization: Describing a Condition or Prescriptive Design Principle, in M. Egeberg and P. Laegreid, eds. Organizing Political Institutions: Essays in Honor of Johan P. Olsen (Oslo: Universiteitsforlaget).

Jones, B. (2001) Politics and the Architecture of Choice (Chicago: University of Chicago Press).

Jones, C. O. (1982) The United States Congress: People, Place and Policy (Homewood, III: Dorsey).

Kickert, W. J. M., E.-H. Klijn and J. F. M. Koopenjan (1997) Managing Complex Networks (London: Sage).

Kingdon, J. (1995) Agendas, Alternatives and Public Policies, 2nd. ed. (New York: Harper/Collins).

Kooiman, J. (1993), "Social-Political Governance: Introduction," in J. Kooiman (ed), Modern Governance: New Government-Society Interactions (Newbury Park, CA: Sage).

March, J. G. and J. P. Olsen (1976) Ambiguity and Choice in Organizations (Bergen: Norwegian University Press). 
March, J. G. and J. P. Olsen (1989) Rediscovering Institutions: The Organizational Basis of Politics (New York: Free Press).

Ministry of Finance (1998) Borgerne og den offentlige sektor (Copenhagen: Finansministeriet).

Morçöl, M. (1996) Fuzz and Chaos: Implications for Public Administration Theory and Research, Journal of Public Administration Research and Theory 6, 315-25.

Moynihan,D. P. (1973) The Politics of Guaranteed Income (New York: Vintage).

Nelson, R. (1968) The Moon and the Ghetto (New York: Norton).

Norris, P. (1996) Critical Citizens (Oxford: Oxford University Press).

Nurmi, H. (1998) Rational Behavior and the Design of Institutions (Cheltenham: Edward Elgar).

Olsen, J. P. (1983) Organized Democracy (Oslo: Universitetsforlaget).

Olsen, J. P. (2001) Garbage Cans, New Institutionalism and the Study of Politics, American Political Science Review 95, 191-98,

Padgett, J. F. (1980) Managing Garbage Can Hierarchies, Administrative Science Quarterly 25, 583-602.

Peters, B. G. (1992) Bureaucratic Politics in the European Union, in A. M. Sbragia, ed., EuroPolitics (Washington, DC: The Brookings Institution).

Peters, B. G. (2001) The Future of Governing, 2nd. ed. (Lawrence: University Press of Kansas).

Peters, B. G. (2002) Governance as a Theory of Comparative Politics, Paper presented to Colloque on Comparative Politics, University of Amiens, May.

Peters and Pierre (2001) Multi-Level Governance: A Faustian Bargain?, paper presented at Conference on Multi-Level Governance, University of Sheffield, July.

Peters, B. G. and F. Van Nispen (1998) Policy Instruments and Public Policy (Cheltenham: Edward Elgar). 
Phidd, R. \& G. B. Doern (1978), The Politics and Management of the Canadian Economy Policy, (Toronto: Macmillan).

Pierre, J. (1997) Partnerships in Urban Governance: European and American Experiences (Basingstoke: Macmillan).

Pierre, J. and B. G. Peters (2000) Governance, the State and Public Policy (Basingstoke: Macmillan).

Pierson, P. (1994) Dismantling the Welfare State? (Cambridge: Cambridge University Press).

Rhodes, R. A. W. (1996), "The New Governance: Governing Without Governance," Political Studies, 44:652-67.

Rhodes, R. A. W. (2000) Governance and Public Administration, in J. Pierre, ed., Debating Governance (Oxford: Oxford University Press).

Richardson, J. J. (2001) Policy-making in the EU: Interests. Ideas and Garbage Cans of Primeval Soup, in Richardson, ed., European Union: Power and Policy-making, 2nd. ed. (London: Routledge).

Ringeling, A. (2002) An Instrument is Not a Tool, Paper presented at Conference on Policy Instruments, McGill School of Law, Montreal, Ontario, September 26-27.

Sabatier, P. (1988) An Advocacy-Coalition Model of Policy Change and the Role of Policy Oriented Learning Therein, Policy Sciences 21, 129-68.

Salamon, L. (2002a) Handbook of Policy Instruments (New York: Oxford University Press).

Salamon, L. (2002b) Introduction: The New Governance, in Salamon, ed. Handbook of Policy Instruments.

Sbragia, A. (2002) Governance Through Steering, in J. Pierre, Debating Governance (Oxford: Oxford University Press).

Schmitter, P. (1974) Still the Century of Corporatism?, Review of Politics.

Simon, H. A. (1947) Administrative Behavior (New York: Free Press).

Sorenson, E. (1997) Democracy and Empowerment, Public Administration 75, 553-67. 
22-B. Guy Peters / Governance: A Garbage Can Perspective - I H S

Tarrow, S. (1998) Power in Movement: Social Movements and Contentious Politics, 2nd. ed., (Cambridge: Cambridge University Press).

Wiarda, H. (1997) Corporatism and Comparative Politics: The Other Great "Ism" (Armonk, NY: M. E. Sharpe).

Woodside, K. (1992) Trade and Industrial Policy: Hard Choices, in: M.M. Atkinson [ed.], Governing Canada: Institutions and Public Policy (Toronto: Harcourt Brace Jovanovich Canada). 
Author: B. Guy Peters

Title: "Governance: A Garbage Can Perspective"

Reihe Politikwissenschaft / Political Science Series 84

Editor: Peter Biegelbauer

Associate Editor: Gertrud Hafner

ISSN: $1605-8003$

(C) 2002 by the Department of Political Science, Institute for Advanced Studies (IHS),

Stumpergasse 56, A-1060 Vienna • 正 +43 159991-0 • Fax +43 159991-555 • http://www.ins.ac.at 
ISSN: 1605-8003 